\title{
Krav til formelle rutiner for det selvmordsforebyggende arbeid i sykehus
}

Ved prosjektmedarbeider Wenche Hauk $\varnothing$, Handlingsplan mot selvmord, Statens helsetilsyn

Det er for tiden stor aktivitet $i$ landets fylker og kommuner med igangsetting av selvmordsforebyggende tiltak. Modellforsøkene forutsetter en form for samarbeid som overskrider forvaltningsnivåer og profesjonsog sektorgrenser. I den forbindelse får vi $i$ Statens helsetilsyn ofte spørsmål om hvilke formelle bestemmelser som gjelder for ansvarsfordeling mellom de ulike samarbeidspartnerne, om lovligheten $i$ a registrere selumordsforsøkerne og om hvordan bestemmelsene om taushetsplikten skal praktiseres.

Bærumsmodellens rutiner for registrering, behandling og oppfølging av selvmordsfors $\emptyset$ kere ble sist revidert i desember 1995 og godkjent av Statens helsetilsyn, helserettsavdelingen i brev av 21. februar 1996. Det anbefales at andre sykehus praktiserer de formelle retningslinjer for det selvmordsforebyggende arbeidet på tilsvarende måte som ved Bærum sykehus. Det er ellers opp til det enkelte sykehus og dets samarbeidspartnere å velge en funksjonell, lokal utforming for selve behandlingen og oppfølgingen av selvmordsfors $\varnothing$ kerne. Behandling og oppfølging vil ikke bli omtalt her. Viser til Statens helsetilsyns skriftserie nr. 1-96, Bærumsmodellen 1984-1994, som ble omtalt i Nytt i suicidologi nr. 1, 1996.

\section{Ansvarsfordeling, registrerings- rutiner og praktisering av taushetsplikten}

\section{Ansvarsfordeling}

Det må avklares hvem som er medisinsk-faglig ansvarlig i sykehuset for det selvmordsforebyggende arbeidet. Ved Bærum sykehus er dette ansvaret tillagt avdelingsoverlegen ved medisinsk avdeling. En person må være administrativt ansvarlig for driften av tiltaket. I Bærumsmodellen er dette ansvaret tillagt sykehusets sjefsosionom. I den respektive kommune/etat må det faglige ansvaret tillegges en person eller funksjon. Samarbeidet mellom sykehuset og andre etater formaliseres gjennom skriftlige rutiner. Det må nedfelles i rutinene at samarbeidet er gjensidig forpliktende. Hvem som har faglig behandlingsansvar, må også defineres i rutinene. I et sykehus er det overordnede ansvar for all undersøkelse og behandling av pasientene og journalføring av denne virksomhet tillagt leger. Loven åpner likevel for at legen kan delegere deler av disse oppgavene til annet personell så fremt oppgavene kan utføres forsvarlig (legeloven $\$ 17$, $\$ 25$ og $§ 43$ og journalforskriften $\$ 10$ ). Ved Bærum sykehus arbeider sosionomene på skriftlig delegasjon fra sjeflegen. Det betyr bl.a en delegert rett til å registrere pasientinformasjon og plikt til å journalføre informasjonene. Sosionomene foretar en psykososial intervensjon, vurderer suicidalfare og behov for viderebehandling eller oppfølging. Dette arbeidet foregår i nært samarbeid med postlegen. Psykiatrisk konsulent har naturligvis selvstendig behandlingsansvar, og i tillegg veiledningsansvar overfor sosionomene og de andre teammedlemmene.

Tilsvarende veiledningsansvar har faglig leder i de kommunale teamene. Helsesøsters oppgaver i forhold til de selvmordstruede er av forebyggende art og i samsvar med det ansvar som ellers er tillagt helses $\emptyset$ sterfunksjonen i kommunene, hjemlet i kommunehelsetjenesteloven. I Bærumsmodellen har helsesøster oppfølgingsansvar.

\section{Registreringsrutiner}

\section{Mottakelsen}

Alle personer som kommer til sykehuset på grunn av intoksikasjoner eller selvbeskadigelser, registreres særskilt på eget ark i mottakelsen. Avdelingssykepleier i mottakelsen er ansvarlig for at registreringen er fullstendig. Sjefsosionom er ansvarlig for at informasjonen hentes hver morgen. Sjef-

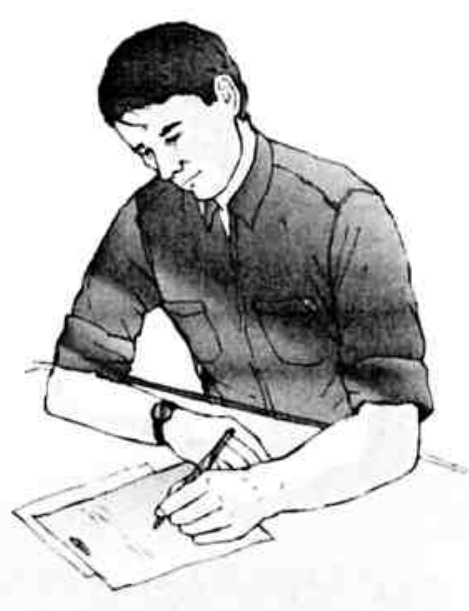

sosionom er også ansvarlig for at alle selvmordsfors $\varnothing$ kerne på listen får et tilbud om behandling eller oppfølging uavhengig av om de er innlagt ved eget sykehus, annet sykehus eller har reist hjem etter medisinsk behandling $\mathrm{i}$ mottakelsen. "Bærumsmodellens rutiner" gir en detaljert beskrivelse av hvordan dette forgår i praksis, og det blir derfor ikke gjentatt her.

Registreringsskjema som del av journal (B-journal)

Pasientene informeres av lege/sykepleier om at samtale med sosionom eller psykiater er en del av de faste behandlingsrutinene ved selvmordsfor$s \emptyset \mathrm{k}$. Sosionomtjenesten har utarbeidet et registreringsskjema som fylles ut under oppsummeringen av den kliniske samtalen med den selvmordstruede.

Skjemaet kan også fungere som intervjuguide. Bruk av registreringsskjemaet medfører ikke behov for egen konsesjon. Begrunnelsen ligger i det som er sagt ovenfor om de plikter og rettigheter som er nedfelt i delegasjonsavtalen og at dette registreringsskjema har 
status som del av pasientjournalen (definert som B-journal). Deler av informasjonene på registreringsskjemaet brukes på de tverretatlige samarbeidsmøtene med kommunehelsetjenesten for videreføring av nødvendige opplysninger. Pasienten er på forhånd orientert om dette (se nedenfor om taushetsplikten). Informasjonene anonymiseres og benyttes $i$ arbeidet med årsmeldinger.

B-journalene/registreringsskjemaene kan oppbevares i arkivskap hos den som har det administrative ansvaret for samarbeidet rundt selvmordsfors $\varnothing \mathrm{k}$ erne. Ved Bærum sykehus oppbevares registreringsskjemaene i sosionomtjenestens arkiv $\mathrm{i}$ inntil ett år. Deretter går de til sykehusets sentralarkiv (jf. journalforskriftene). Det er ikke anledning til å opprette andre former for personregistre i det selvmordsforebyggende arbeidet uten \&̊ søke Datatilsynet om konsesjon.

\section{Taushetsplikten}

Bestemmelser om taushetsplikten er hjemlet $i$ to hovedsett av regler, profesjonslovene og lover som regulerer virksomheten $\mathrm{i}$ offentlig forvaltning. De ulike profesjonslovene hjemler den yrkesmessige taushetsplikten som er mer omfattende enn den forvaltningsmessige. Når det gjelder pasientrettet virksomhet, er det profesjonslovenes bestemmelser om praktisering av taushetsplikten som gjelder. Legelovens bestemmelser om taushetsplikten (fra \$31) gjelder også for sosionomer og sykepleiere i sykehuset $\mathrm{i}$ den grad de er å anse som legens medhjelper.

I henhold til legelovens $\$ 34$ er taushetsplikten ikke til hinder for at annet helsepersonell gis opplysninger om en pasient dersom dette er nødvendig av hensyn til undersøkelse eller behandling av pasienten. Bestemmelsene om taushetsplikten kan derfor ikke forhindre tverrfaglig samarbeid mellom yrkesgruppene $\mathrm{i}$ sykehuset.

\section{Opphevelse av taushetsplikten}

Når det gjelder samarbeid i selvmordsforebyggende team som involverer personell fra andre forvaltningsnivåer og sektorer, kan spørsmål om opphevelse av taushetsplikten løses på to måter.

\section{Ved skriftlig samtykke}

Den enkleste måten å få opphevet taushetsplikten på, er å innhente samtykke fra pasienten. For barn under 16 år må foreldre/verge samtykke (legeloven § 32). Ved Bærum sykehus praktiseres skriftlig samtykke fra pasienten basert på grundig muntlig og skriftlig informasjon.

Et informasjonsskriv som skal brukes til skriftlig opphevelse av taushetsplikten, må inneholde konkret og tydelig informasjon om de selvmordsforebyggende teamenes sammensetning og funksjon. Pasientens underskrift gjelder kun opphevelse av taushetsplikten. Kopi av det undertegnede skrivet legges $\mathrm{i}$ journalen. Originalen beholder pasienten selv. Det innhentes ikke skriftlig samtykke for henvisning til kontakt med helsesøster eller andre. Henvisning til videre behandling og opp øølging baseres på muntlig samtykke. Oppfølging av helsesøster er frivillig. Alle tiltak som iverksettes, skal journalføres.

\section{Ved presumptivt samtykke}

Dette er aktuelt i de tilfeller hvor pasienten har reist hjem på eget ansvar eller forsvunnet fra sykehuset uten at taushetsplikten er skriftlig opphevet, og uten at den suicidale handlingen er tilstrekkelig kartlagt. De få pasientene dette angår, vil først få et brev fra sosionomtjenesten med informasjon om at helsesøster kommer til å bli varslet og vil ta kontakt, med mindre pasienten selv kontakter sykehuset og reserverer seg. Pasienten gis på denne måten alltid en reell mulighet til å motsette seg at sykehuset varsler helsesøster. Hvis pasienten ikke har gitt tilbakemelding innen en uke, anses det som stilltiende/ presumert samtykke til opphevelse av taushetsplikten, og vedkommende henvises til helsesøster for oppfølging. Det vil her føre for langt å gå inn på de faglige begrunnelser som ligger bak denne oppsøkende holdningen. Det viser seg at svært få reserverer seg. Denne muligheten for å oppheve taushetsplikten uten direkte samtykke er tatt med $i$ Bærumsmodellens rutiner for at alle selvmordsfors $\emptyset$ kerne som har vært i kontakt med sykehuset, skal få et reelt tilbud om hjelp og støtte.

\section{Opplysningsplikt}

I visse tilfeller skal enkelte informasjoner gis uten hinder av taushetsplikten og etter eget initiativ til sosialtjenesten og/eller barneverntjenesten (legeloven $\$ \$ 34$ a. og 34 b.).

Opplysningsplikten medfører at sosialtjenesten skal varsles når sykehuset mottar en gravid og det er grunn til å tro at hun "misbruker rusmidler på en slik måte at det er overveiende sannsynlig at barnet vil bli født med skade". Jf. lov om sosiale tjenester \$6-2a. Det er sjelden sykehusene mottar gravide selvmordsfors $\varnothing$ kere, men det kan ikke utelukkes.

Barneverntjenesten er viktige medspillere og skal varsles når pasienten er under 18 år og det er grunn til å tro at vedkommende blir mishandlet $\mathrm{i}$ hjemmet, eller at det

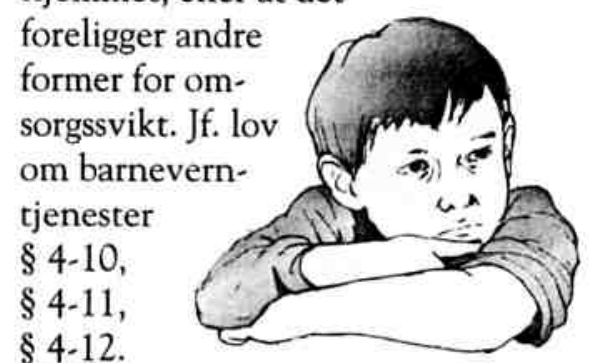
$\S 4-12$.

Opplysningsplikten medfører også at det skal gis melding til barnevernet hvis selvmordsforsøkeren har barn som blir uten tilsyn/omsorg på grunn av foreldrens helsetilstand. Situasjoner som utløser meldinger til barnevernet med foreldrenes samtykke, omtales ikke her.

Fortsetter side 16 
Han skriver videre:

På grunn av verksemdsteorien si vektlegging av slike sosiale prosessar i og mellom ulike samfunnsnivå, greier teorien å fange opp eksporttanken i sitt vokabular.

Hauge utvikler også ansatser om selvmordsforebygging på basis av virksomhetsteorien. Han hevder at virksomhetsteoriens helhetlige menneskesyn ikke mister individnivået, men ser problemet selvmord ut fra det indre, dialektiske forholdet mellom individet og samfunnet, og mer helhetlig - individet og omverden (andre mennesker, natur, gjenstander, levende liv, ting osv.). I og med at forklaringen ligger i virksomheteni forholdet, i kommunikasjonsprosessen - blir ikke den enkelte som fors $ø$ ker å bryte livet stemplet som abnorm eller syk, men som et menneske som

1

"treng ein ny type feed-back/nye responskanalar, kanalar hvis innhald må dannast gjennom samspel med omgjevnadane" (sitat sammendrag).

Hauges forebyggingsstrategiske tanker har følgende feste - basert på at han ser selvmord og selvmordsforsøk i et indre forhold:

fortsatt fra side 10

\section{Konklusjon}

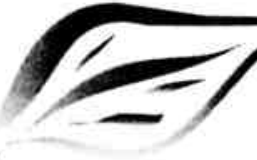

For at det selvmordsforebyggende arbeidet skal oppfylle lovers og forskrifters formelle krav til pasientrettet virksomhet må følgende forutsetninger være til stede: Det må være en bestemt lege som har det overordnede medisinsk-faglige ansvar for tiltaket. Det må foreligge en klar og tydelig delegasjonsavtale fra lege som definerer det øvrige personellets myndighetsområde. Registreringene må utformes som del av pasientjournalen, og taushetsplikten skal som hovedregel oppheves ved skriftlig samtykke fra pasienten. Disse forutsetningene må nedfelles i skriftlige rutiner.

\section{Referanser:}

Bærumsmodellens rutiner, Bærum sykehus, des. 1995

Brev av 21. febr.1996, vedr. registreringsrutiner i Bærumsmodellen, fra Statens helsetilsyn

Lov om leger av 13. juni, 1980, nr. 42

Lov om sykehus m.v. av 19. juni 1969, nr. 57

Lov om helsetjeneste i kommuner av 19. nov. 1982, nr. 66

Lov om helses $\phi$ stertjeneste av 19. juni 1982, nr. 66 Lov om sosiale tjenester av 13. des. 1991, nr. 81 Lov om barneverntjeneste av 17. juli 1992, nr. 100 Lov om behandlingsmåten $i$ forvaltningssaker (forvaltningsloven) av 10. febr. 1967
1. Unngår vi sykdomsgiøringen kan flere forstå at dette gjelder også meg. Dette kan være med på å heve fellesinnsatsen mot en utbredelse av selvmord.

2. Unngår vi sykdomsgjøring kan vi også gjøre det lettere for den som tenker på selvmord å stå fram med problemene sine; mennesker man m $\phi$ ter blir da en hjelpe- og omsorgsressurs ved siden av ekspertisen.

3. Ved å se på dødsvirksomhet under ett, blir omfanget større. Det kvalitative innholdet og det kvantitative omfanget blir annerledes. Dette kan få flere til - og på en bedre måte - å forstå nyansene i problemet.

4. Ved å likestille alvoret i selvmordet og selvmordsfors $\phi \mathrm{k}$, vil sjansene for at vi responderer sterkere på alle typer selvmordsfors $\phi \mathbf{k}$ bli større.

Hauges avhandling er et svært viktig bidrag til selvmordsforskningen, og da særlig til registrerings- og forebyggingspraksisen. Avhandlingen er også et viktig bidrag til den sosiologiske, psykologiske og sosialfilosofiske skoleretningen som kalles virksomhetsteorien.

Denne hovedoppgaven kan lånes via nærmeste bibliotek eller kjøpes direkte fra Nils-Petter Hauge, 6880 Stryn. Pris: kr. 200.

\section{Konferanse om forskning og forebygging, Rica Sjolyst Oslo, 23. - 24. jan. 1997.}

Universitetet i Oslo arrangerte i samarbeid med Handlingsplan mot selvmord en konferanse på Sjølyst med vel 250 deltakere fra hele landet. Statsråd Gudmund Hernes åpnet konferansen, og Ellen Hagemo i Statens helsetilsyn orienterte om den nasjonale planen mot selvmord.

Undertegnede gjennomgikk så epidemiologi og risikofaktorer, og presenterte utviklingen vi har hatt i Norge, i de øvrige skandinaviske land og i Europa. (De mest sentrale data ble presentert i "Nytt i suicidologi" nr. 1/96). Lars Mehlum gjennomgikk deretter selvmordsforebygging og intervensjon; hvor står vi, og hvor går vi hen? Det nasjonale kompetansesenteret i Oslo og de regionale kompetansesentrene i Bergen, Trondheim og Tromsø ble også presentert.

Det var satt opp en rekke parallellsesjoner, der ulike aspekter innen området selvmord ble behandlet: Selvmord blant ungdom, selvmord og høyrisikogrupper, sosiokulturelle og biologiske faktorer, intervensjon og behandling, forebyggelsesmodeller, forskningsmetodologi og etterlatte ved selvmord. Sesjonene var godt besøkt, og det ble mye diskusjon og meningsutveksling i tillegg til fremleggelse av stoffet. Til slutt ble etiske problemer i forbindelse med selvmord gjennomgått. Biskop Sigurd Osberg foresto en interessant og lærerik presentasjon etterfulgt av paneldebatt omkring emnet: "Selvmordsforebygging: Etikk - veivalg?"

De fleste av foredragene foreligger i resymés form, og kan bestilles v/Seksjon for selvmordsforskning -og forebygging.

Et betydelig engasjement også fra deltakernes side lover godt for fremtiden $\mathrm{i}$ norsk suicidologi. Det er tydelig at emnet er satt på dagsorden, og at Handlingsplanen er kommet godt på skinnene. Muligens vil et tilsvarende landsomfattende seminar bli arrangert $\mathrm{i}$ den avsluttende fasen av Handlingsplanen.

Et evalueringsskjema bekreftet det positive inntrykket vi fikk under konferansen: De aller fleste var begeistret, ikke minst over å treffe kolleger og få faglig påfyll. Mange påpekte også den høye faglige kvaliteten og variasjonen $\mathrm{i}$ foredragene og parallellsesjonene.

Nils Retterstøl 